A $\mathrm{Cublications}$ Rec. Nat. Prod. 12:4 (2018) 397-402

\title{
Antioxidant Activity of Flaxseed (Linum usitatissimum L.) shell and Analysis of Its Polyphenol Contents by LC-MS/MS
}

\author{
Hatica Han ${ }^{1 \S}$, Hasibe Yılmaz ${ }^{* 2}$ and İlhami Gülçin ${ }^{* 1}$ \\ ${ }^{1}$ Atatürk University, Faculty of Sciences, Department of Chemistry, 25240-Erzurum,Türkiye \\ ${ }^{2}$ TUBITAK UME, Chemistry Group Laboratories, P.O. Box: 54, 41470-Gebze, Kocaeli, Türkiye
}

(Received September 22, 2017; Revised December 29, 2017; Accepted January, 12, 2018)

\begin{abstract}
Flaxseed (Linum usitatissimum L.) is important source of oil and protein for industrial, pharmaceutical, and nutritional applications. In order to estimate the effects of lyophilized aqueous extract of flaxseed shell (AEF) and evaporated ethanolic extract of flaxseed shell (EEF), we studied their DPPH, ABTS, DMPD and $\mathrm{O}_{2}{ }^{--}$scavenging effects. Total antioxidant activity by ferric thiocyanate method, $\mathrm{Fe}^{3+}, \mathrm{Cu}^{2+}$ and $\left[\mathrm{Fe}^{3+}-\right.$ $\left.(\mathrm{TPTZ})_{2}\right]^{3+}$ reducing ability, and $\mathrm{Fe}^{2+}$ chelating activity. Also, $\alpha$-tocopherol, BHA, trolox, and BHT were used as positive controls. The results clearly AEF and EEF demonstrated effective antioxidant activity. The quantity of $p$-hydroxybenzoic, vanillin, $p$-coumaric acid, ascorbic acid, ferulic acid, and ellagic acid were investigated by LC-MS/MS. The present study will introduce a novelty for further studies on the antioxidant effects of AEF and EEF.
\end{abstract}

Keywords: Flaxseed; Linum usitatissimum; antioxidant activity; polyphenol content $(0) 2018$ ACG Publications. All rights reserved.

\section{Plant Source}

Flaxseed (Linum usitatissimum L.) is an annual herb belonging to the Linaceae family obtained from local market of Erzurum in 2011. This plant has been cultivated for oil, fiber, and food because of its beneficial chemical composition. The plant material was identified by Prof. Dr. Yusuf Kaya, Ataturk University, Erzurum, Turkey.

\section{Previous Studies}

Plant materials contain a lot of bioactive phenolics, which demonstrate biological activity including antiradical, antioxidant, antimicrobial and anticancer effects. These chemical classes have many beneficial health effects and prevent some chronicle diseases [1]. Antioxidants are synthetic or natural compounds that can delay some types of cell damage and quench reactive radical species formed during oxidative reactions in metabolism. They include mainly phenols, polyphenols, carotenoids, anthocyanins and tocopherols, which main groups of phytochemicals found in plants [2]. The basic structure of phenol contains a hydroxyl group $(-\mathrm{OH})$ linked to the aromatic ring. The biological activates of phenolic compounds differ depending on the position and number of phenolic groups and their locations [3]. Vegetables and fruits are main resources of naturally occurred antioxidants and reduce risks of certain diseases. Natural antioxidants have been associated with cancer development are generally opted by consumers because of their safety [4]. Therefore, the identification and the corresponding importance of natural antioxidant sources need to be researched from the standpoint of health-improving properties [5]. On the other hand, it was reported that support

\footnotetext{
* Corresponding author: E-Mail: igulcin@atauni.edu.tr

$\S$ She passed away at the date of 29 October 2014.
} 
the usage of natural antioxidant additives decrease oxidative stress level and chronic disease [6]. Also, it was reported that synthetic antioxidants have shown side effects including mutagenic, carcinogenic and toxic impacts. For this reason, the usage of these synthetic compounds has been restricted due to theirs undesired effects $[5,6]$. Because of the restrictions, an interest has been given to the antioxidants from natural sources. It was well known that plant constituents have antioxidant activity and free radicals scavenging effects. So, there is an increasing demand in safer and natural antioxidants for food, biological and pharmaceutical systems. Also, there are increasing trends in consumer preference towards natural and safer antioxidants from plants origin [7].

\section{Present Study}

In the study, we first determined the antioxidant activities of AEF and EEF using different antioxidant activities including DPPH, DMPD, ABTS and $\mathrm{O}_{2}{ }^{-}$scavenging effects, total antioxidant activity-ferric thiocyanate method (FTC), $\mathrm{Cu}^{2+}$ and $\mathrm{Fe}^{3+}$ reducing abilities and metal chelating activity. Also, a significant purpose of this study was to show the main polyphenols in AEF and EEF by LCMS/MS analysis.

Flaxseed was lyophilized as described previously [8]. Also, evaporated ethanolic extraction of flaxseed was obtained according to the previous method [5]. Total phenolics in AEF and EEF were measured by Folin-Ciocalteu reagent [4-6] and calculated as $\mu \mathrm{g}$ of GA equivalents (GAE) per one $\mathrm{mg}$ of dried extract. Total flavonoids in AEF and EEF were estimated using the $\mathrm{AlCl}_{3}$ [9]. They were calculated as $\mu \mathrm{g}$ of quercetin equivalents $(\mathrm{QE})$ per one mg dried extract. LC-MS/MS technique was used for evaluation the quantitative content of phenolics in AEF and EEF [10]. Standard chromatogram and chromatogram of phenols in AEF and EEF by LC-MS/MS (mg/mL) was summarized in Figure 1.

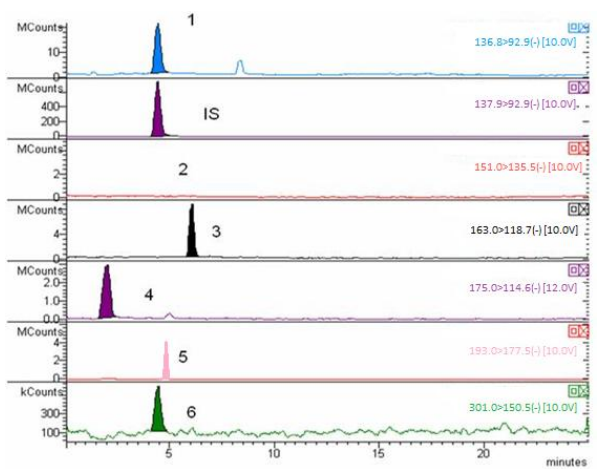

AEF

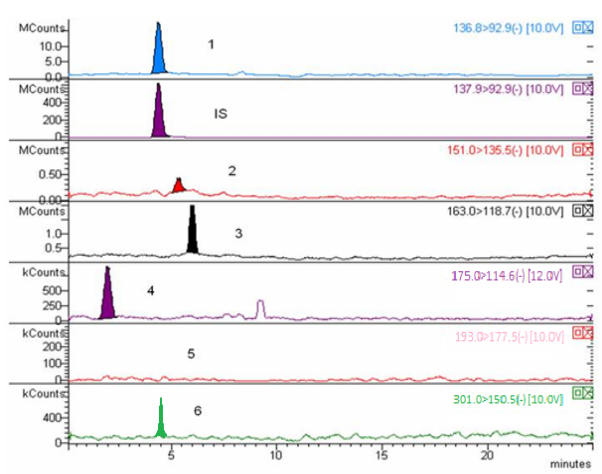

EEF

Figure 1. Chromatograms of phenolic antioxidants by LC-MS/MS

The experiments of validation and linearity of the used method for the indicated phenolics, the recovery of the experiments, the validation of parameters were determined for linearity, recovery, repeatability, limits of the detection (LOD), and quantification (LOQ) experiments, procedures of uncertainty were given previously [11]. Total antioxidant activity of AEF and EEF was performed according to FTC. $\mathrm{Fe}^{3+}$ reducing power was measured by reduction of $\mathrm{Fe}^{3+}$ [12] and $\mathrm{Fe}^{3+}-\mathrm{TPTZ}$ complexes as described previously [13]. $\mathrm{Cu}^{2+}$ reducing capacity was done according to Apak et al. [14]. Metal chelating capacity was determined by disrupting of $\mathrm{Fe}^{2+}$-ferrozine complex formation. Antiradical effects of AEF and EEF were determined by using the DPPH, $\mathrm{DMPD}^{{ }^{+}}, \mathrm{O}_{2}{ }^{--}$, and $\mathrm{ABTS}^{\circ+}$ scavenging [15]. The percentage of inhibition of lipid peroxidation, percentage of $\mathrm{Fe}^{2+}$ chelating and scavenging capabilities of radicals were calculated using the equation of $\mathrm{A}(\%)=(1-\lambda \mathrm{s} / \lambda \mathrm{c}) \mathrm{x} 100$ [16]. Where in $\mathrm{A}$ is the scavenged or chelated effect. $\lambda_{\mathrm{C}}$ and $\lambda_{\mathrm{S}}$ are absorbances of control and sample, respectively [17]. $\mathrm{IC}_{50}$ values indicate of the sample concentration, which was a required half concentration of sample for scavenging or chelating [18].

Plants have been used for treatment of many diseases [19]. Phenolic compounds are the most widely occurring chemicals, which having strong antioxidant properties [20]. The phenolic contents 
$(\mathrm{mg} / \mathrm{g})$ in AEF and EEF were determined using the formula of $\mathrm{y}=0.001 \mathrm{x},\left(\mathrm{r}^{2}: 0.970\right)$. They were given as gallic acid equivalents (GAE) and found as 45.0 GAE/g for AEF and 167.0 GAE/g EEF. Phenolic compounds exhibit their antioxidant activity due to their redox property. According to the results obtained from LC-MS/MS analysis, the main phenolic acids in AEF and EEF were found to be phydroxybenzoic acid, ellagic acid, p-coumaric acid, ferulic acid and ascorbic acid, respectively. Ellagic acid (57 and $9 \mathrm{mg} / \mathrm{kg}$ ), ellagic acid ( 85 and $13 \mathrm{mg} / \mathrm{kg}$ ), p-coumaric acid (192 and $30 \mathrm{mg} / \mathrm{kg}$ ) and p-hydroxybenzoic acid (779 and $120 \mathrm{mg} / \mathrm{kg}$ ) were abundantly found in AEF and EEF, respectively (Table 1$)$.

Recently, there is a growing interest in phenolic compounds, and flavonoids in particularly because of their antioxidant capacity and possible benefits in food and pharmaceutical applications and in human health [21]. The flavonoid contents $(\mathrm{mg} / \mathrm{g})$ in AEF and EEF was estimated using the following calibration curve (y:0.0085x, $\left.\mathrm{r}^{2}: 0.952\right)$. The total flavonoids in AEF and EEF were determined as 23.30 and $3.88 \mathrm{QE} / \mathrm{g}$, respectively.

Antioxidants can easily reduce $\mathrm{Fe}\left[(\mathrm{CN})_{6}\right]_{3}$ to $\mathrm{Fe}\left[(\mathrm{CN})_{6}\right]_{2}$ [22]. AEF and $\mathrm{EEF}$ had effective reducing in $\mathrm{Fe}\left[(\mathrm{CN})_{6}\right]_{3}$ reduction method. As can seen in Table 2 , AEF $\left(\mathrm{r}^{2}: 0.940\right)$ and EEF $\left(\mathrm{r}^{2}: 0.983\right)$ demonstrated effective $\mathrm{Fe}^{3+}$ reducing ability $(\mathrm{p}<0.01)$ and increased steadily with increased concentrations. The reducing power of AEF, EEF and standard compounds were found as follows: BHA $\left(1.811, \mathrm{r}^{2}: 0.973\right)$, BHT $\left(1.300, \mathrm{r}^{2}: 0.965\right)>$ Trolox $\left(1.034, \mathrm{r}^{2}: 0.989\right)>\operatorname{EEF}\left(0.340, \mathrm{r}^{2}: 0.983\right)>\alpha-$ Tocopherol $\left(0.240, \mathrm{r}^{2}: 0.935\right)>\operatorname{AEF}\left(0.198, \mathrm{r}^{2}: 0.940\right)$. Reduction $\mathrm{Fe}\left[(\mathrm{CN})_{6}\right]_{3}$ by antioxidants gives the intensive Perl's Prussian blue complex [23].

$\mathrm{Cu}^{2+}$-neocuproine reducing power of AEF, EEF and standards $(30 \mu \mathrm{g} / \mathrm{mL})$ was shown in Table 2: $\operatorname{BHT}\left(0.828, \mathrm{r}^{2}: 0.981\right)>$ BHA $\left(0.619, \mathrm{r}^{2}: 0.960\right) \approx$ trolox $\left(0.618, \mathrm{r}^{2}: 0.996\right)>\operatorname{EEF}\left(0.437, \mathrm{r}^{2}: 0.952\right) \approx$ $\alpha$-Tocopherol $\left(0.433, \mathrm{r}^{2}: 0.909\right)>\operatorname{AEF}\left(0.172, \mathrm{r}^{2}: 0.938\right)$. Copper is a vital component for several endogenous antioxidant enzymes. It is known that well-regulated copper levels in diet had positive effects on cancer [24].

Table 1. LC-MS/MS results of selected phenolics and quantity of antioxidants in AEF and EEF (in $\mathrm{mg} / \mathrm{kg}$, AEF: aqueous extract of flaxseed shell, EEF: ethanol extract of flaxseed shell)

\begin{tabular}{|c|c|c|c|c|c|c|}
\hline \multirow[t]{2}{*}{ No } & \multirow[t]{2}{*}{ Compounds } & \multirow{2}{*}{$\begin{array}{l}\text { Parent } \\
\text { Ion }\end{array}$} & \multirow{2}{*}{$\begin{array}{l}\text { Daughter } \\
\text { Ion }\end{array}$} & \multirow{2}{*}{$\begin{array}{l}\text { Collision } \\
\text { Energy (V) }\end{array}$} & \multicolumn{2}{|c|}{$\begin{array}{c}\text { Amount of } \\
\text { antioxidants }(\mathrm{mg} / \mathrm{kg})^{\S}\end{array}$} \\
\hline & & & & & AEF & EEF \\
\hline 1 & $p$-Hydroxybenzoic acid & 136.8 & 92.9 & 10 & 779 & 120 \\
\hline 2 & Vanillin & 151.0 & 135.5 & 10 & - & 8 \\
\hline 3 & $p$-Coumaric acid & 163.0 & 118.7 & 10 & 192 & 30 \\
\hline 4 & Ascorbic acid & 175.0 & 114.6 & 12 & 57 & 9 \\
\hline 5 & Ferulic acid & 193.0 & 177.5 & 10 & 71 & - \\
\hline 6 & Ellagic acid & 301.0 & 150.5 & 10 & 85 & 13 \\
\hline IS $^{*}$ & ${ }^{13} \mathrm{Cp}$-Hydroxybenzoic acid & 137.9 & 92.9 & 10 & - & - \\
\hline
\end{tabular}

Table 2. Antioxidant activity of AEF, EEF and standards at the same concentration $(30 \mu \mathrm{g} / \mathrm{mL}$; AEF: aqueous extract of flaxseed shell, EEF: ethanol extract of flaxseed shell, BHT: butylated hydroxytoluene, BHA: butylated hydroxyanisole)

\begin{tabular}{lccccccc}
\hline & $\begin{array}{c}\text { Total antioxidant } \\
\text { activity }\end{array}$ & \multicolumn{2}{c}{$\begin{array}{c}\mathbf{F e}^{\mathbf{3 +}} \\
\text { reducing }\end{array}$} & \multicolumn{2}{c}{$\mathbf{C u}^{\mathbf{2 +}}$} & \multicolumn{2}{c}{$\begin{array}{c}\text { FRAP } \\
\text { redity }\end{array}$} \\
\cline { 2 - 8 } & $\boldsymbol{\lambda}_{\mathbf{5 0 0}}$ & $\boldsymbol{\lambda}_{\mathbf{4 5 0}}$ & $\mathbf{r}^{\mathbf{2}}$ & $\boldsymbol{\lambda}_{\mathbf{4 5 0}}$ & $\mathbf{r}^{\mathbf{2}}$ & $\boldsymbol{\lambda}_{\mathbf{5 9 3}}$ & $\mathbf{r}^{\mathbf{2}}$ \\
\hline BHA & 89.90 & 1.811 & 0.973 & 0.619 & 0.960 & 2.272 & 0.983 \\
BHT & 94.90 & 1.300 & 0.965 & 0.828 & 0.981 & 1.049 & 0.959 \\
Trolox & 93.10 & 1.034 & 0.989 & 0.618 & 0.996 & 1.672 & 0.995 \\
a-Tocopherol & 52.51 & 0.240 & 0.835 & 0.433 & 0.995 & 0.433 & 0.909 \\
AEF & 73.95 & 0.198 & 0.940 & 0.172 & 0.938 & 0.489 & 0.941 \\
EEF & 87.23 & 0.340 & 0.983 & 0.437 & 0.952 & 0.525 & 0.953 \\
\hline
\end{tabular}

The FRAP assay measures the antioxidants ability to reduce $\left[\mathrm{Fe}^{3+}-(\mathrm{TPTZ})_{2}\right]^{3+}$ complex [24]. The most effective $\left[\mathrm{Fe}^{3+}-(\mathrm{TPTZ})_{2}\right]^{3+}$ reducing power was measured in BHA $\left(2.272, \mathrm{r}^{2}: 0.983\right)$. This activity was greater than Trolox $\left(1.672, \mathrm{r}^{2}: 0.995\right)>\operatorname{BHT}\left(1.049, \mathrm{r}^{2}: 0.959\right)>\operatorname{EEF}\left(0.525, \mathrm{r}^{2}: 0.953\right) \approx$ AEF $\left(0.489, \mathrm{r}^{2}: 0.941\right)>\alpha$-Tocopherol $\left(0.433, \mathrm{r}^{2}: 0.959\right.$, Table 2$)$. Also, a similar circumstance was 
observed for the antioxidant capacity of AEF and EEF measured by either ABTS, CUPRAC or FRAP assays.

As seen in Table 3, AEF and EEF had a potent $\mathrm{Fe}^{2+}$ chelating effect $(\mathrm{p}<0.01)$. $\mathrm{IC}_{50}$ values for the $\mathrm{Fe}^{2+}$ chelating capacities of AEF and EEF were found as $9.24 \mu \mathrm{g} / \mathrm{mL}\left(\mathrm{r}^{2}: 0.931\right)$ and $8.88 \mu \mathrm{g} / \mathrm{mL}$ $\left(\mathrm{r}^{2}: 0.917\right)$. On the other hand, BHA had $\mathrm{IC}_{50}$ value of $24.75 \mu \mathrm{g} / \mathrm{mL}\left(\mathrm{r}^{2}: 0.995\right)$, BHT had $\mathrm{IC}_{50}$ value of $8.56 \mu \mathrm{g} / \mathrm{mL}\left(\mathrm{r}^{2}: 0.821\right), \alpha$-tocopherol had $\mathrm{IC}_{50}$ value of $17.76 \mu \mathrm{g} / \mathrm{mL}\left(\mathrm{r}^{2}: 0.939\right)$ and Trolox had $\mathrm{IC}_{50}$ value of $7.07 \mu \mathrm{g} / \mathrm{mL}\left(\mathrm{r}^{2}: 0.840\right)$. These results obtained from this test clearly showed that $\mathrm{Fe}^{2+}$ binding effect of AEF and EEF was similar to BHT and Trolox, but higher than that of BHA and $\alpha$-tocopherol.

$\mathrm{DPPH} \cdot \mathrm{DMPD}^{\circ+}$ and $\mathrm{ABTS}^{\circ+}$ reacts with an antioxidant compounds and can easily give hydrogen atoms [24]. The results showed that AEF and EEF showed effective radical scavenging effects when compared to BHT, BHA, Trolox and $\alpha$-Tocopherol (Table 3). $\mathrm{IC}_{50}$ values of DPPH. scavenging for AEF, EEF, and standards on the DPPH radical were found as $53.30 \mu \mathrm{g} / \mathrm{mL}\left(\mathrm{r}^{2}: 0.934\right)$ for AEF, $49.50 \mu \mathrm{g} / \mathrm{mL}\left(\mathrm{r}^{2}: 0.966\right)$ for EEF, $6.42 \mu \mathrm{g} / \mathrm{mL}\left(\mathrm{r}^{2}: 0.778\right)$ for BHA, $38.50 \mu \mathrm{g} / \mathrm{mL}\left(\mathrm{r}^{2}: 0.843\right)$ for BHT, $5.87 \mu \mathrm{g} / \mathrm{mL}\left(\mathrm{r}^{2}: 0.932\right)$ for $\alpha$-Tocopherol and $34.65 \mu \mathrm{g} / \mathrm{mL}\left(\mathrm{r}^{2}: 0.922\right)$ for Trolox (Table 3$)$. Second improved radical scavenging technique is $\mathrm{ABTS}^{*+}$ scavenging activity. $\mathrm{IC}_{50}$ values for $\mathrm{AEF}$ and EEF in this assay were $27.72 \mu \mathrm{g} / \mathrm{mL}\left(\mathrm{r}^{2}: 0.945\right)$ and $25.56 \mu \mathrm{g} / \mathrm{mL}\left(\mathrm{r}^{2}: 0.962\right)$. Also, $\mathrm{IC}_{50}$ values belongs to DMPD $^{++}$scavenging for BHA, BHT, $\alpha$-Tocopherol and Trolox were found as $9.90 \mu \mathrm{g} / \mathrm{mL}$ $\left(\mathrm{r}^{2}: 0.881\right), 9.45 \mu \mathrm{g} / \mathrm{mL}\left(\mathrm{r}^{2}: 0.842\right), 33.00 \mu \mathrm{g} / \mathrm{mL}\left(\mathrm{r}^{2}: 0.989\right)$ and $49.50 \mu \mathrm{g} / \mathrm{mL}\left(\mathrm{r}^{2}: 0.919\right)$, respectively. DMPD can form a steady and colored DMPD $^{*+}$ cation. DMPD ${ }^{*+}$ had a maximum absorbance at 505 $\mathrm{nm}$. $\mathrm{IC}_{50}$ for $\mathrm{AEF}$ and $\mathrm{EEF}$ was found as $28.88 \mu \mathrm{g} / \mathrm{mL}\left(\mathrm{r}^{2}: 0.924\right)$ and $27.72 \mu \mathrm{g} / \mathrm{mL}\left(\mathrm{r}^{2}: 0.914\right)$, respectively. $\mathrm{IC}_{50}$ was found as $22.35 \mu \mathrm{g} / \mathrm{mL}$ for BHA $\left(\mathrm{r}^{2}: 0.793\right)$ and $21.00 \mu \mathrm{g} / \mathrm{mL}$ for Trolox $\left(r^{2}: 0.711\right)$.

Table 3. $\mathrm{IC}_{50}$ values of $\mathrm{DPPH}^{*}$ scavenging, $\mathrm{DMPD}^{++}$scavenging, $\mathrm{ABTS}^{++}$scavenging and $\mathrm{O}_{2}^{-{ }^{-}}$scavenging activities and $\mathrm{Fe}^{2+}$ binding effects of AEF, EEF and standards

\begin{tabular}{|c|c|c|c|c|c|c|c|c|c|c|}
\hline \multirow[t]{2}{*}{ Compounds } & \multicolumn{2}{|c|}{$\begin{array}{c}\text { DPPH• } \\
\text { scavenging }\end{array}$} & \multicolumn{2}{|c|}{$\begin{array}{c}\text { ABTS }^{\bullet+} \\
\text { scavenging }\end{array}$} & \multicolumn{2}{|c|}{$\begin{array}{c}\text { DMPD }^{\circ+} \\
\text { scavenging }\end{array}$} & \multicolumn{2}{|c|}{$\begin{array}{c}\mathrm{O}_{2}{ }^{--} \\
\text {scavenging }\end{array}$} & \multicolumn{2}{|c|}{$\begin{array}{c}\mathrm{Fe}^{2+} \\
\text { chelating }\end{array}$} \\
\hline & $\mathrm{IC}_{50}$ & $\mathbf{r}^{2}$ & $\mathrm{IC}_{\mathbf{5 0}}$ & $\mathbf{r}^{2}$ & $\mathrm{IC}_{50}$ & $\mathbf{r}^{2}$ & $\mathrm{IC}_{50}$ & $\mathbf{r}^{2}$ & $\mathrm{IC}_{50}$ & $\mathbf{r}^{2}$ \\
\hline BHA & 6.42 & 0.778 & 9.90 & 0.881 & 22.35 & 0.793 & 13.59 & 0.762 & 24.75 & 0.933 \\
\hline BHT & 38.50 & 0.843 & 9.49 & 0.842 & $-{ }^{* *}$ & $-{ }^{* *}$ & 23.10 & 0.830 & 8.56 & 0.821 \\
\hline$\alpha$-Tocopherol & 5.87 & 0.932 & 33.00 & 0.989 & _** & - $^{* *}$ & 26.65 & 0.855 & 17.76 & 0.939 \\
\hline Trolox & 34.65 & 0.922 & 49.50 & 0.919 & 21.00 & 0.964 & 19.80 & 0.960 & 7.07 & 0.840 \\
\hline AEF & 53.30 & 0.934 & 27.72 & 0.945 & 28.88 & 0.924 & 49.50 & 0.969 & 9.24 & 0.931 \\
\hline EEF & 49.50 & 0.966 & 25.67 & 0.962 & 24.75 & 0.914 & 24.75 & 0.978 & 8.88 & 0.917 \\
\hline
\end{tabular}

As can seen Table 3, $\mathrm{IC}_{50}$ values of scavenging of $\mathrm{O}_{2}{ }^{-}$generation by same concentration of $\mathrm{AEF}$ and EEF and the other molecules were given. AEF and EEF were powerful inhibiting effects on $\mathrm{O}_{2}{ }^{-}$generation. $\mathrm{IC}_{50}$ value of $\mathrm{O}_{2}{ }^{--}$scavenging effects of $\mathrm{AEF}$ and $\mathrm{EEF}$ were found to be 49.50 $\left(\mathrm{r}^{2}: 0.969\right) \mu \mathrm{g} / \mathrm{mL}$ and $24.75\left(\mathrm{r}^{2}: 0.978\right) \mu \mathrm{g} / \mathrm{mL}$ (Table 3). These values were calculated as $13.59 \mu \mathrm{g} / \mathrm{mL}$ $\left(\mathrm{r}^{2}: 0.978\right)$ for BHA, $23.10 \mu \mathrm{g} / \mathrm{mL}\left(\mathrm{r}^{2}: 0.978\right)$ for BHT, $26.65 \mu \mathrm{g} / \mathrm{mL}\left(\mathrm{r}^{2}: 0.978\right)$ for $\alpha$-Tocopherol and $19.80 \mu \mathrm{g} / \mathrm{mL}\left(\mathrm{r}^{2}: 0.978\right)$ for Trolox. It is obvious from these results $\mathrm{O}_{2}^{--}$scavenging activities of AEF and EEF are close standard compounds.

In conclusion, $\mathrm{AEF}$ and $\mathrm{EEF}$ were found as important antioxidant source in different in vitro bioanalytical tests like reducing abilities, total antioxidant activity, $\mathrm{Fe}^{2+}$ binding activities, and radical scavenging activities. Also, quantities of some phenolics including $p$-hydroxybenzoic, vanillin, $p$ coumaric acid, ascorbic acid, ferulic acid, and ellagic acid were successfully characterized by LCMS/MS and $p$-hydroxybenzoic acid was the most abundant phenolic compound in both AEF and EEF. Also, this plant has been cultivated for fiber as well as a functional food because of its beneficial chemical composition, such as, tocopherols oils, fats enriched in $\omega 3$ fatty acids, crude fiber, protein and antioxidants in its seed. These components are probably also responsible for its antioxidant activity [25].

\section{ORCID}

Hatica Han: She passed away, thus she had not an ORCID ID.

Hasibe Y1lmaz:0000-0002-1308-1650

İlhami Gülçin: 0000-0001-5993-1668 


\section{References}

[1] H. Tohma, E. Köksal, Ö. Kılıç, Y. Alan, M.A. Yılmaz, İ. Gülçin, E. Bursal and S.H. Alwasel (2016). RPHPLC/MS/MS analysis of the phenolic compounds, antioxidant and antimicrobial activities of Salvia L. species, Antioxidants, 5, 38.

[2] İ. Gülçin (2012). Antioxidant activity of food constituents-An overview, Archiv. Toxicol. 86, 345-396.

[3] M. Topal, H. Gocer, F. Topal, P. Kalin, P. Polat Köse, İ. Gülçin, K. Cetin Çakmak, M. Küçük, L. Durmaz, A.C. Gören and S.H. Alwasel (2016). Antioxidant, antiradical and anticholinergic properties of cynarin purified from the illyrian thistle (Onopordum illyricum L.), J. Enzyme Inhib. Med. Chem. 31, 266-275.

[4] L. Polat Köse, İ. Gülçin, A.C. Gören, J. Namiesnik, A.L. Martinez-Ayala and S. Gorinstein (2015). LCMS/MS analysis, antioxidant and anticholinergic properties of galanga (Alpinia officinarum Hance) rhizomes, Ind. Crops Prod. 74, 712-721.

[5] P. Kalın, İ. Gülçin and A.C. Gören (2015). Antioxidant activity and polyphenol content of Vaccinium macrocarpon, Rec. Nat. Prod. 9, 496-502.

[6] M. Iş1k, M. Korkmaz, E. Bursal, İ. Gülçin, E. Köksal and H. Tohma (2015). Determination of antioxidant properties of Gypsophila bitlisensis, Int. J. Pharmacol., 11, 366-371.

[7] H. Yılmaz, S. Çarıkçı, T. Kılıç, T. Dirmenci, T. Arabacı and A.C. Gören (2017). Screening of chemical composition, antioxidant and anticholinesterase activity of section Brevifilamentum of Origanum (L.) species, Rec. Nat. Prod. 11(5), 439-455.

[8] H. Göçer and İ. Gülçin (2011). Caffeic acid phenethyl ester (CAPE): Correlation of structure and antioxidant properties, Int. J. Food Sci. Nutr. 62, 821-825.

[9] H. Özbek, Z. Güvenalp, T. Özek, H.G. Sevindik, H. Yuca, K.Ö. Yerdelen and L.Ö. Demirezer (2017). Chemical composition, antioxidant and anticholinesterase activities of the essential oil of Origanum rotundifolium Boiss. from Turkey, Rec. Nat. Prod. 11(5), 485-490.

[10] İ. Gülçin, E. Bursal, H.M. Şehitoğlu, M. Bilsel and A.C. Gören (2010). Polyphenol contents and antioxidant activity of lyophilized aqueous extract of propolis from Erzurum, Turkey, Food Chem. Toxicol. 48, 2227-2238.

[11] T. Ak and İ. Gülçin (2008). Antioxidant and radical scavenging properties of curcumin, Chem. Biol. Interact. 174, 27-37.

[12] M.H. Sehitoglu, H. Han, P. Kalin, İ. Gülçin, A. Ozkan and H.Y. Aboul-Enein (2015). Pistachio (Pistacia vera L.) gum: A potent inhibitor of reactive oxygen species, J. Enzyme Inhib. Med. Chem. 30, 264-269.

[13] İ. Gülçin, E. Bursal, H.M. Şehitoğlu, M. Bilsel, and A.C. Gören (2010). Polyphenol contents and antioxidant activity of lyophilized aqueous extract of propolis from Erzurum. Turkey, Food Chem. Toxicol. 48, 2227-2238.

[14] R. Apak, K. Güçlü, M. Özyürek, S.E. Karademir and E. Erçal (2006). The cupric ion reducing antioxidant capacity and polyphenolic content of some herbal teas, Int. J. Food Sci. Nutr. 57, 292-304.

[15] İ. Gülçin, (2012). Antioxidant activity of food constituents-An overview. Archiv. Toxicol. 86, 345-396.

[16] N.B. Reddy, C.S. Sundar, B.S. Krishna, S. Santhisudha, P. Sreelakshmi, S.K. Nayak and C.S. Reddy (2017). Cellulose- $\mathrm{SO}_{3} \mathrm{H}$ catalyzed synthesis of bis( $\alpha$-aminophosphonates) and their antioxidant activity, Org. Commun. 10(1), 46-55.

[17] N. Öztaşkın, P. Taslimi, A. Maraş, S. Göksu and İ. Gülçin (2017). Novel antioxidant bromophenols with acetylcholinesterase, butyrylcholinesterase and carbonic anhydrase inhibitory actions, Bioorg. Chem. 74, 104-114.

[18] S. Çakmakçı, E.F. Topdaş, P. Kalın, H. Han, P. Şekerci, L. Polat Kose and İ. Gülçin (2015). Antioxidant capacity and functionality of oleaster (Elaeagnus angustifolia L.) flour and crust in a new kind of fruity ice cream, Int. J. Food Sci. Technol. 50, 472-481.

[19] İ. Gülçin, S. Beydemir, F. Topal, N. Gagua, A. Bakuridze, R. Bayram and A. Gepdiremen (2012). Apoptotic, antioxidant and antiradical effects of majdine and isomajdine from Vinca herbacea Waldst. and kit, J. Enzyme Inhib. Med. Chem. 27, 587-594.

[20] İ. Gülçin, F. Topal, S.B. Oztürk Sarikaya, E. Bursal, A.C. Gören and M. Bilsel (2011). Polyphenol contents and antioxidant properties of medlar (Mespilus germanica L.), Rec. Nat. Prod. 5, 158-175.

[21] E. Köksal, E. Bursal, E. Dikici, F. Tozoğlu and I. Gülçin (2011). Antioxidant activity of Melissa officinalis leaves, J. Med. Plants Res., 5, 217-222.

[22] L. Polat Köse and İ. Gulcin (2017). Inhibition effects of some lignans on carbonic anhydrase, acetylcholinesterase and butyrylcholinesterase enzymes, Rec. Nat. Prod. 11(6), 558-561.

[23] E. Bursal and İ. Gülçin (2011). Polyphenol contents and in vitro antioxidant activities of lyophilized aqueous extract of kiwifruit (Actinidia deliciosa), Food Res. Int. 44, 1482-1489. 
[24] H. Şerbetçi Tohma and İ. Gülçin (2010). Antioxidant and radical scavenging activity of aerial parts and roots of Turkish liquorice (Glycyrrhiza glabra L.). Int. J. Food Propert. 13, 657-671.

[25] X.G. Zou, X.L. Chen, J.N. Hu, Y.F. Wang, D.M. Gong, X.M. Zhu and Z.Y. Deng (2017). Comparisons of proximate compositions, fatty acids profile and micronutrients between fiber and oil flaxseeds (Linum usitatissimum L.). J. Food Comp. Anal. 62, 168-176.

\section{A C G \\ publications \\ (c) 2018 ACG Publications}

